\title{
Have You Considered Eating Your Weeds?
}

\author{
Willem Sternberg Jansen van Rensburg, Michele Cloete, Abe Shegro Gerrano, \\ Patrick Olusanmi Adebola \\ Agricultural Research Council—Vegetable and Ornamental Plant Institute, Pretoria, South Africa \\ Email: wjvrensburg@arc.agric.za
}

Received 21 January 2014; revised 25 February 2014; accepted 14 March 2014

Copyright (C) 2014 by authors and Scientific Research Publishing Inc.

This work is licensed under the Creative Commons Attribution International License (CC BY). http://creativecommons.org/licenses/by/4.0/

(c) (i) Open Access

\begin{abstract}
In most parts of the developed world, Pigweed, Spider plant, Lambs amongst others are regarded as weeds. But in Africa and other developing countries, these plants form part of the daily diets of many rural households. The oldest inhabitants of South Africa have harvested leaves from wild plants to supplement the meat from hunted animals. Over 100 different species of plants are cooked as a potherb/relish with corn meal. These species include indigenous species as well as indigenized, mostly weedy, species. These species became part of the African culture and heritage and were collectively known as morogo or imifino. The popularity of specific species is a function of many factors, including availability, ease of preparation, taste, consistency and appearance. Some popular genera are Amaranthus, Cleome, Solanum and Corchorus. Micronutrient malnutrition is widespread in South Africa with vitamin A and iron as the major concern for micronutrient deficiency. Morogo can contribute to alleviating these micronutrient deficiencies. It was found that for the species tested, that morogo are low in energy and that leaves of nightshade, pigweed and spider flower provided more than $50 \%$ of the RDA for vitamin A.
\end{abstract}

\section{Keywords}

Imifino; Morogo; Pigweed; Spider Flower; Food Security

\section{Introduction}

In most parts of the developed world Amaranthus (Pigweed), Cleome (Spider plant), Chenopodium (Lambs quarters), Bidens (Black Jack) and Corchorus (Jute) species are regarded as weeds [1]. But in Africa and other developing countries, these plants form part of the daily diets of many rural households [2]. The oldest inhabitants of South Africa, the San people and the first hunter-gatherers have harvested leaves from wild plants to supplement the meat from hunted animals. The women gathered the wild plants to supplement their diet of the meat hunted by the men. Over 100 different species of plants are cooked as a potherb/relish with corn meal (Zea 
mays) or used as relishes or side dishes in South Africa [3]. These species include indigenous species as well as indigenized, mostly weedy, species. These species became part of the African culture and heritage and were collectively known as morogo or imifino (from here on collectively referred to as morogo) Many of these species are still wild harvested from the veldt and fallow lands and play a very important role in rural and urban household food security [2].

\section{Edible Weeds}

What exactly constitutes morogo is subject to area, time and ethnic background. The plant species that are included depend on the local ecology and culinary traditions [4]-[6]. If the focus is on the use rather than the origin of plant species, the term allows for the addition of new species to the collective, including fairly recently introduced exotic species. In fact, the term morogo are used for all green leafy vegetables that are used, irrespective of whether they are from traditional indigenous plants or from conventional crops such as pumpkins, beetroots or sweet potatoes [7].

Morogo are harvested from the wild or from fallowed and cultivated fields where it grows as weeds. The young growing points and tender leaves are the parts of the plants that are used in the preparation of vegetable dishes [6]. The morogo are prepared as potherbs and may be prepared from a single species or from a combination of different species [7]. Other ingredients, such as tomatoes, onions, peanut flour and spices are added to the leafy vegetables to enhance their taste. Morogo are normally boiled or steamed. The first cooking water of very bitter species like Solanum retroflexum and Bidens pilosa may be replaced by fresh water, before addition of the other leafy vegetables [8] [9]. The recipes used to prepare the different leafy vegetable dishes tend to be fairly homogeneous [9].

The consumption of morogo is highly variable and depends on factors such as poverty status, degree of urbanisation, distance to fresh produce markets and time of year [6]. The use of wild food, including morogo, is part of a very important safety net that rural people use to cope with food security, poverty, disaster or livelihood stress [10]-[12]. In poor rural communities consumption of morogo is particularly important to supplement the nutrition of women and children [9] [13]. In contrast, urban households use less morogo than rural households, because they have better access to fresh markers, and are distantly removed from areas where these vegetables grow [14].

Morogo is seldom marketed, and marketing South Africa is limited and is mostly restricted to dried products [6] [14] [15]. Whitbread (1986) [16] reported the marketing of different species of amaranth which were collected as weeds from fields and gardens in the Kwazulu-Natal Midlands.

In South Africa morogo is mostly wild harvested. Several of the most popular morogo species, such as pigweed and spider flower, are pioneer plants which emerge naturally when soils are disturbed as a result of cultivation. They are regarded as weeds in commercial farming systems [17], but not in African smallholder cropping systems. Women, who do most of the weeding in smallholder cropping systems, often distinguish between undesirable weed species, which are hoed or pulled out, and morogo, which are harvested or left undisturbed for subsequent use [15]. Morogo mostly grow in summer, with exceptions such as local Brassica species and Chenopodium album which grow during winter [4] [16].

The popularity of specific species is a function of many factors, including availability, ease of preparation, taste, consistency and appearance. Pigweed is used almost all over because of its wide distribution and adaptability. The soft, fast-cooking leaves are preferred to the coarse leaves which require long cooking times [18]. Other important factors include regional and gender diversity, age, and the influence of taste. The bitter taste of nightshade and cleome are highly appreciated, particularly by males in the northern parts of South Africa, whereas people in the southern part of South Africa prefer the "sweet" taste of pigweed leaves is preferred [6]. Similarly, many people in the north enjoy the mucilaginous texture of jute whereas people in the south find the sliminess offensive [6].

Some important edible weeds in South Africa are:

\subsection{Pigweed (Amaranthus spp. L)}

Amaranth belongs to the family Amaranthaceae and is an extremely variable, erect to spreading, herbaceous herb (Figure 1). It grows as a weed almost worldwide and is used in many countries as either a vegetable or for grain [1] [19]. The young leaves, growing points and whole seedlings of Pigweed are harvested and cooked for 


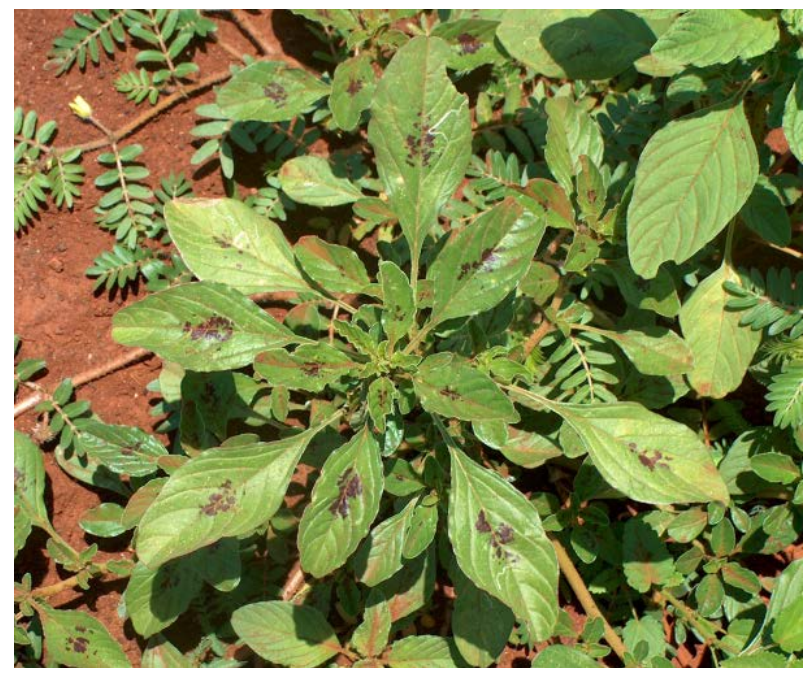

Figure 1. Amaranthus graecizans have spoon shaped leaves with dark markings on the leaves in certain areas.

use as a vegetable. Pigweed has also got other uses. The leaves and stems of A. spinosis are dried and ground for use as snuff [15]. Pigweed can also be used to make a salt substitute. Whole dried plants of different Pigweed species were burnt to ash that was dissolved in water. The mixture is then filtered and the precipitate is used as a salt substitute [18].

\subsection{Spider Flower (Cleome gynandra L.)}

Spider flower is an herbaceous, erect, mainly branched plant with distinctive palmate leaves with three to seven leaflets (Figure 2). Stems and leaves are covered with glandular hair. Cleome gynandra is the most widely used as a leafy vegetable but $C$. monophylla and $C$. hirta, which are close relatives, are also used occasionally [5] [18]-[21]. The plant parts used include the leaves and the growth tips. Some people find spider flower too bitter, but the bitterness can be reduced by changing the cooking water or by cooking it in milk or sour milk. Pigweed leaves are often added to increase bulk [5] [15] [18]-[21].

\subsection{Nightshade (Solanum nigrum Complex)}

Nightshades (S. nigrum complex) are erect, branched annual or biannual herbaceous plants. Nightshade is also well known for its small, shiny, black to purple-black fruit that is used in jams [18]. The nightshade complex contains many species and its taxonomy is complicated. In South Africa S. americanum, S. nigrum and S. retroflexum are the most commonly used species [20] [22]. When used as a leafy vegetable, the leaves and tender shoots of nightshade are harvested and cooked [8], but reports in the literature indicated that the leaves can also be eaten raw [18]. The ripe fruit is also consumed extensively, either fresh or as a preserve, but the green fruit is poisonous [18].

\subsection{Jute (Corchorus spp.)}

Jute is an erect annual herb that varies from $20 \mathrm{~cm}$ to approximately $1.5 \mathrm{~m}$ in height. The leaves have distinct hair-like teeth at the base [18]. Different jute species are used, namely Corchorus asplenifolius, $C$ trilocularis, $C$. tridens and C. olitorius [5]. Cooked Jute has a mucilaginous or slimy texture, similar to okra, which is highly appreciated by some and offensive to others. Bicarbonate of soda or even cow urine is added to the cooking water to reduce the sliminess. According to the older ladies, Jute leaves are prepared with coarse-textured leaves, such as those of cowpeas, to makes it easier for older people to swallow. Certain Jute species are also used as a fibre crop [5] [21].

Many other weed species are utilised as morogo, some of these are presented in Table 1 . The use of many of these are sometimes localised, but other species, like purslane (Figure 3) [18], are even used in the North Africa 
Table 1. Some weedy species used as morogo [1] [5].

\begin{tabular}{cc} 
Species & Common name \\
\hline Bidens pilosa and B bipinata & Blackjack \\
Sonchus oleraceus & Milk thistle \\
Taraxacum officinale & Dandelion \\
Chenopodium album & Lamb's quarters or White goose foot \\
Momordica balsemima & Balsam pear \\
Capselle bursa-pastoris & Shepard's purse \\
Raphanus raphaistrum & Wild radish \\
Malva parviflora & Small mallow \\
Portulaca oleracea & Purslane \\
Physalis angulata & Wild gooseberry \\
Urtica urens & Stinging nettle \\
Tribulus terrestris & Devil's thorn \\
\hline
\end{tabular}

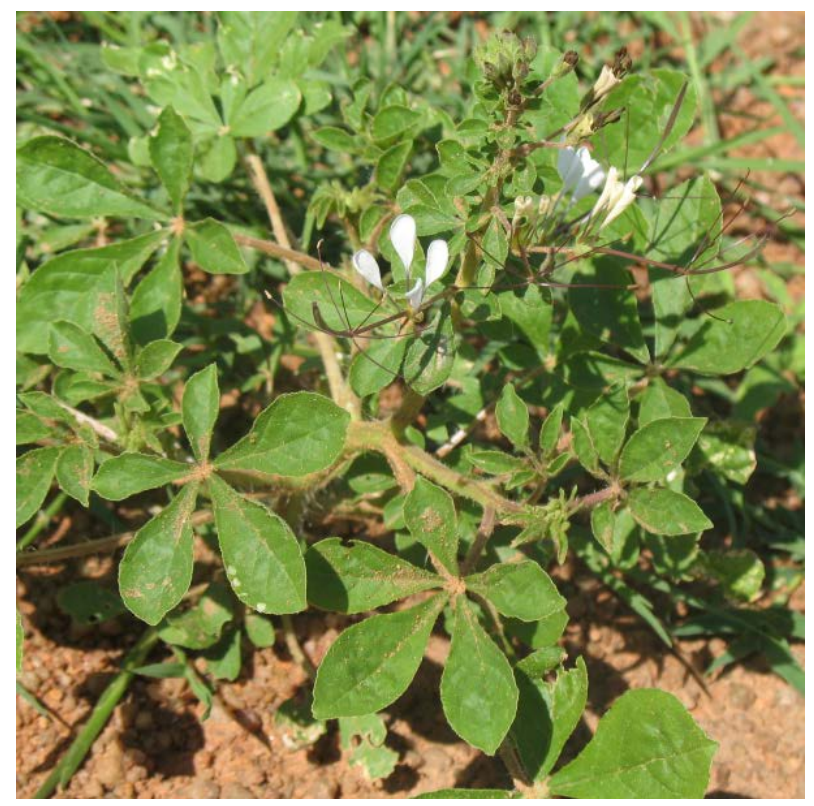

Figure 2. The compound leaves and spidery flowers of Cleome gynandra.

and the Middle East [20]. Medicinal properties are also attributed to some of the morogo species like balsam pear (Figure 4) [6] [15]. There is no clear indication for which plants are edible or not. One of the best indications is to draw on the knowledge of the local people [23].

\section{The Potential of African Morogo to Improve Human Nutrition}

Micronutrient malnutrition is widespread in South Africa with vitamin A and iron as the major concern for micronutrient deficiency. Generally dark green leaves are a source for nutrients such as beta-carotene, vitamin C, protein, calcium and iron. Morogo are high in bulk and low in protein, fat and energy, mainly because of their high water content and the major contribution of leaves towards nutrient intake is in terms of carotenoids (lutein and $\beta$-carotene), vitamin C and folate in particular [24]. Micronutrient analysis also showed that a portion of 


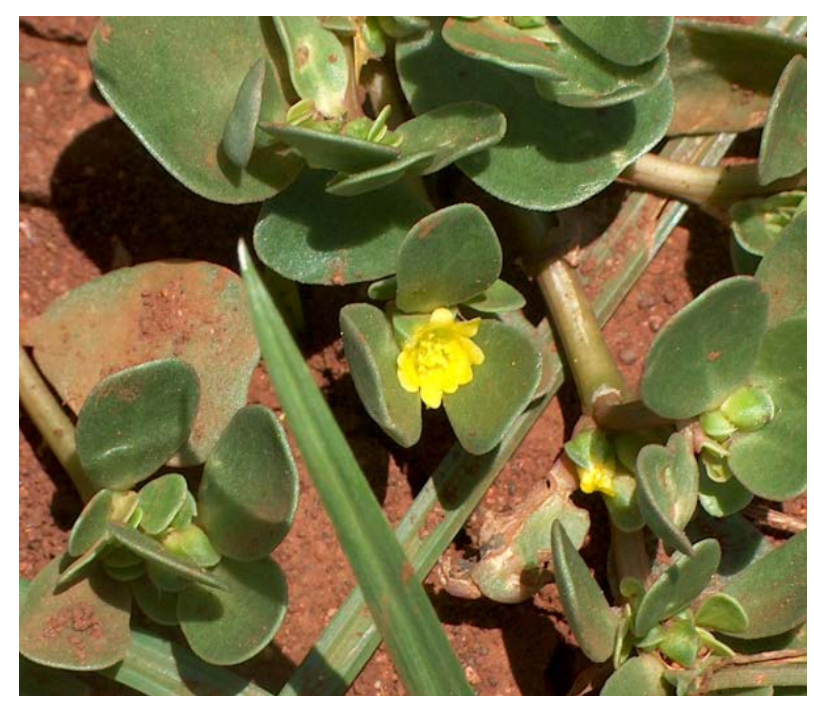

Figure 3. The succulent leaves of Portulaca oleracea (purslane) is also used in the Middle East and North Africa.

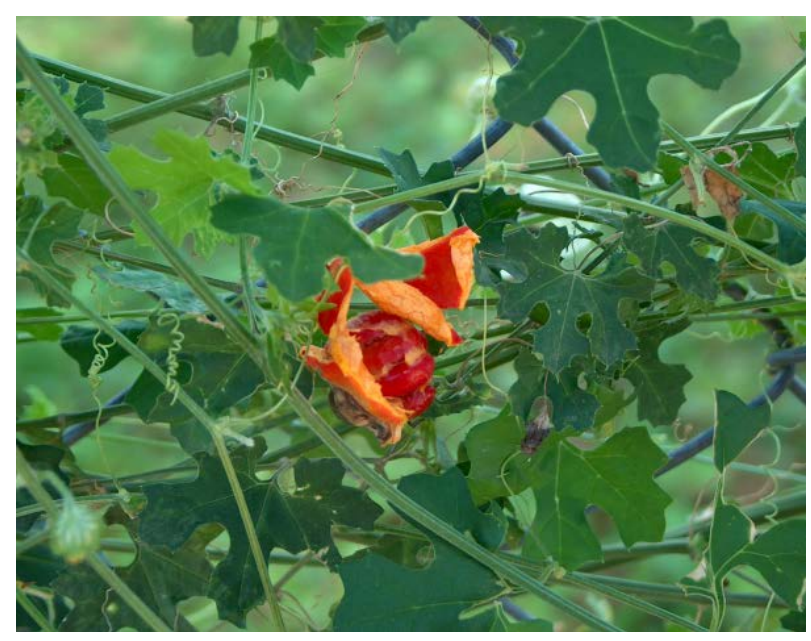

Figure 4. Momordica balsemima is a creeper that grows on the fences. It is said to contain medicinal properties.

cooked leafy vegetables would make a significant contribution to the daily requirement of women for iron, vitamin C, folate and beta-carotene [25]-[27]. However, it is important to keep in mind that dark green leafy vegetables are known to contain oxalates, phytates and nitrates, compounds that reduce absorption of these micronutrients [25].

Estimated nutrient contribution of an average portion size a of leaves of African leafy vegetables to the recommended dietary allowance (RDA) for children aged 4 - 8 years and women per portion size of $90 \mathrm{~g}$ cooked morogo for young children and $130 \mathrm{~g}$ cooked morogo for females using a yield factor of 1.3 from raw to cooked (Table 2) [24]. It was found that for the species tested, that morogo are low in energy ( $<5 \%$ of the estimated requirement) and that morogo provided $10 \%$ or less of the RDA for 19 - 30-year-old females for protein (except for spider flower. Leaves of nightshade, pigweed and spider flower provided more than $50 \%$ of the RDA for vitamin A [24].

\section{Conclusion}

There is a well-known Pedi proverb, "Meat is a visitor but morogo a daily food" that demonstrates the important role of morogo in the daily lively hoods of South Africans. Morogo are still used extensively by rural house-holds, 
Table 2. Estimated nutrient contribution of an average portion size of leaves of African leafy vegetables to the recommended dietary allowance (RDA) estimated energy requirements (EER) for children aged 4 - 8 years and women aged 19 - 30 years (adapted from [24] [28]).

\begin{tabular}{|c|c|c|c|c|c|c|c|}
\hline & Unit & Nightshade & Pigweed & Jute & Spider Flower & Cabbage & Swiss Chard \\
\hline \multirow{2}{*}{ Energy } & \% EER 4 - 8 y & 2 & 3 & 3 & 2 & 1 & 2 \\
\hline & \% EER 19 - 30 y & 2 & 3 & 3 & 2 & 1 & 2 \\
\hline \multirow{2}{*}{ Protein } & \% RDA 4 - 8 y & 2 & 15 & 12 & 19 & 5 & 14 \\
\hline & \% RDA 19 - 30 y & 1 & 9 & 7 & 11 & 4 & 10 \\
\hline \multirow{2}{*}{ Magnesium } & \% RDA 4 - 8 y & 47 & 124 & 44 & 39 & 7 & 43 \\
\hline & \% RDA 19 - 30 y & 28 & 74 & 27 & 23 & 2 & 15 \\
\hline \multirow{2}{*}{ Iron } & $\%$ RDA 4 - 8 y & 48 & 34 & 24 & 14 & 4 & 23 \\
\hline & \% RDA 19 - 30 y & 38 & 27 & 19 & 11 & 2 & 18 \\
\hline \multirow{2}{*}{ Folate } & \% RDA 4 - 8 y & 13 & 17 & 10 & 27 & 6 & 11 \\
\hline & \% RDA $19-30$ y & 9 & 12 & 7 & 20 & 3 & 6 \\
\hline \multirow{2}{*}{ Vitamin C } & $\%$ RDA $4-8 y$ & 8 & 3 & 2 & 4 & 8 & 24 \\
\hline & \% RDA $19-30$ y & 4 & 1 & 1 & 2 & 2 & 8 \\
\hline \multirow{2}{*}{ Vitamin A } & \% RDA 4 - 8 y & 70 & 89 & 55 & 72 & 1 & 86 \\
\hline & \% RDA 19 - 30 y & 57 & 73 & 45 & 59 & 0.25 & 43 \\
\hline
\end{tabular}

EER = estimated energy requirements; EER $(\mathrm{kJ})$ for $4-8$ years is the mean of 7316 (EER for boys) and $6896($ EER for girls $)=7106$. RDA = recommended dietary allowance, which is the average daily dietary intake level that is sufficient to meet the nutrient requirement of nearly all (97\% - 98\%) healthy individuals in a particular life stage and gender group.

even in a modern South Africa. If the potential nutritional value of morogo is taken into account, it can contribute in a major way to the food security and balanced diets of rural households. It is therefore clear that there is more to some of the common weeds than meets the eye, and that one can really consider eating them.

\section{References}

[1] Bromilow, C. (1995) Problem Plants of South Africa. Briza Publications, Pretoria, 315 p.

[2] Jansen van Rensburg, W.S., van Awerbeke, W., Slabbert, R., Faber, M., van Jaarsveld, P., van Heerden, I., Wenhold, F. and Oelofse, A. (2007) African Leafy Vegetables in South Africa. Water SA, 33, 317-326.

[3] Wehmeyer, A.S. and Rose, E.F. (1983) Important Indigenous Plants Used in the Transkei as Food Supplements. Bothalia, 13, 613-615.

[4] Levy, H.F., Weintroub, D. and Fox, F.W. (1936) The Food Value of Some Common Edible Leaves. South African Medical Journal, 10, 669-707.

[5] van Wyk, B. and Gericke, N. (2000) People’s Plants. A Guide to Useful Plants of Southern Africa. Briza Publications, Pretoria, $352 \mathrm{p}$.

[6] Vorster, H.J., Jansen van Rensburg, W.S., Van Zijl, J.J.B. and van den Heever, E. (2002) Germplasm Management of African Leafy Vegetables for the Nutritional and Food Security Needs of Vulnerable Groups in South Africa. Progress Report, ARC-VOPI, Pretoria.

[7] Faber, M., van Jaarsveld, P.J. and Laubscher, R. (2007) The Contribution of Dark-Green Leafy Vegetables to Total Micronutrient Intake of Two- to Five-Year-Old Children in a Rural Setting. Water SA, 33, 407-412.

[8] van Averbeke, W. and Juma, K.A. (2006) The Cultivation of Solanum retroflexum Dun. in Vhembe, Limpopo Province, South Africa. International Symposium on the Nutrition and Water Use of Indigenous Crops for Improved Livehoods, 19-20 September 2006, University of Pretoria, Pretoria, The Centre for Nutrition, University of Pretoria, Pretoria.

[9] Vorster, H.J., Jansen van Rensburg, W.S., Venter, S.L. and van Zijl, J.J.B. (2005) (Re)-Creating Awareness of Traditional Leafy Vegetables in Communities. Regional Workshop on African Leafy Vegetables for Improved Nutrition, 6-9 December 2005, IPGRI, Nairobi, 7.

[10] Rose, E.F. and Guillarmod, A.J. (1974) Plants Gathered as Foodstuffs by the Transkeian Peoples. Suid-Afrikaanse Mediese Tydskrif, 86, 1688-1690.

[11] Rubaihayo, E.B. (1997) Conservation and Use of Traditional Vegetables in Uganda. In: Guarino, L., Ed., Traditional African Vegetables, IPGRI, Rome, 104-116. 
[12] Shackleton, S.E., Shackleton, C.M. and Cousins, B. (2000) Re-Valuing the Communal Lands of Southern Africa: A New Understanding of Rural Livelihoods. ODI Natural Resource Perspectives, 62, 1-4.

[13] Vorster, H.J. and Jansen van Rensburg, W.S. (2005) The Effect of Participation on All Participants in the Traditional Leafy Vegetable Project in Arthurstone (Bushbuck Ridge). In: Vorster, H.J., Jansen van Rensburg, W.S., Steyn, G.J. and Mashele, X.B., Eds., Particaption and Linkages for Improved Extension Delvery, Proceedings of the 39th Conference, Bloemfontein, 10-12 May 2005, 10-20.

[14] Shackleton, C.M., Shackleton, S.E., Netshiluvhi, T.R., Geach, B.S., Balance, A. and Fairbanks, D.F.K. (2002) Use Patterns and Value of Savannah Resources in Three Rural Villages. Economic Botany, 56, 130-146. http://dx.doi.org/10.1663/0013-0001(2002)056[0130:UPAVOS]2.0.CO;2

[15] Hart, T.G.B. and Vorster, H.J. (2006) Indigenous Knowledge on the South African Landscape-Potentials for Agricultural Development. Urban, Rural and Economic Development Programme, Occasional Paper No 1, HSRC Press, Cape Town, 52.

[16] Whitbread, M.W. (1986) Preliminary Studies on the Utilization and Adaptation of Indigenous and Introduced Vegetable and Grain Amaranths (Amarathus spp.) in the Natal and KwaZulu Midlands. M.Sc. (Agric) Dissertation, University of Natal, Pietermaritzburg.

[17] Grabandt, K. (1985) Weeds of Crops and Garden in South Africa. Ciba-Geigy (Pty) Ltd., Johannesburg, 134 p.

[18] Fox, F.W., Norwood, M.E. and Young, O.X. (1982) Food from the Veld: Edible Wild Plants of Southern Africa. Delta Books, Johannesburg, 399.

[19] Chweya, J.A. and Mnzava, N.A. (1997) Promoting the Conservation and Use of Underutilized and Neglected Crops. 11. Cat's Whiskers. IPGRI, Rome, 53.

[20] Schippers, R.R. (2000) African Indigenous Vegetables. An Overview of the Cultivated Species. Natural Resources Institute/ACP-EU Technical Centre for Agricultural and Rural Cooperation, Chatham, 214.

[21] van Wyk, B. and Gericke, N. (2000) People’s Plants. A Guide to Useful Plants of Southern Africa. Briza Publications, Pretoria, 352.

[22] Manoko, M.L. and van der Weerden, G.M. (2004) Solanumamericanum Mill. In: Grubben, G.J.H., Denton, O.A., Eds., PROTA 2: Vegetables/Légumes. PROTA, Wageningen, 477-480.

[23] Schippers, R.R. (2002) African Indigenous Vegetables, an Overview of the Cultivated Species. Natural Resources Institute, Chatham, 245.

[24] Latham, M.C. (1997) Human Nutrition in the Developing World. FAO, Rome, 508.

[25] van Jaarsveld, P.J., Faberand, M. and van Heerden, I. (2012) Selected Vitamin and Mineral Content of Eight African Leafy Vegetables and Their Potential Contribution to Individual Nutrient Requirements. In: Oelofse, A. and van Averbeke, Eds., Nutritional Value and Water Use of African Leafy Vegetables for Improved Livelihoods, Water Research Commission, Pretoria, 227-243.

[26] Vesamvuni, C., Steyn, N.P. and Potgieter, M.J. (2001) Nutritional Value of Wild, Leafy Plants Consumed by the Vhavenda. South African Journal of Science, 97, 51-54.

[27] Faber, M., van Jaarsveld, P.J. and Laubscher, R. (2007) The Contribution of Dark-Green Leafy Vegetables to Total Micronutrient Intake of Two- to Five-Year-Old Children in a Rural Setting. Water SA, 33, 407-412.

[28] Wolmarans, P., Danster, N., Dalton, A., Rossouw, K. and Schonfeldt, H. (2010) Condensed Food Composition Tables for South Africa. Medical Research Council, Parow Valley, Cape Town, 126. 